\title{
Effects of solar radiation and relative humidity on germination of Botryosphaeriaceae species conidia
}

\author{
N.T. Amponsah, E.E. Jones, H.J. Ridgway and M.V. Jaspers \\ Faculty of Agriculture and Life Sciences, P. O. Box 84, Lincoln University, New Zealand \\ Corresponding author: Nicholas.Amponsah@lincoln.ac.nz
}

\begin{abstract}
Viability and germination of conidia of three Botryosphaeriaceae species, which are important grapevine pathogens, were significantly affected by exposure to different levels of sunlight and relative humidity $(\mathrm{RH})$. After $7 \mathrm{~h}$ exposure to non-filtered sunlight $(+\mathrm{UV})$, filtered sunlight (-UV) and shade, germination differed between light levels, being 35,57 and 81\%, respectively, and after $70 \mathrm{~h}$ exposure it was 0, 21 and 65\%, respectively. Non-germinated conidia were unable to germinate when placed in a moist environment, indicating that they had been killed. High RH favoured germination since 91 and 70\%, respectively, germinated after $3 \mathrm{~h}$ in 100 and 97\% RH. However, in 93\% RH, only 44\% germinated by $24 \mathrm{~h}$ and in $84 \% \mathrm{RH}$ no conidia germinated. The inhibition of germination was temporary since replacement in a moist environment caused conidia to germinate. Light and $\mathrm{RH}$ effects were similar for the three species.
\end{abstract}

Keywords Neofusicoccum luteum, Neofusicoccum australe, Diplodia mutila, solar radiation, humidity, conidia.

\section{INTRODUCTION}

Botryosphaeriaceae species are important fungal pathogens of woody plants worldwide (Slippers \& Wingfield 2007; Lazzizera et al. 2008), but the effects of environmental conditions on their disease cycles are not well understood. In New Zealand, the conidia of Neofusicoccum and Diplodia species, which have been found throughout the year in rain water runoff collected on grapevines (Amponsah et al. 2009), are able to infect freshly pruned grapevine shoots or canes leading to dieback (Amponsah et al. 2008). The ability of these conidia to survive in the environment is an important factor in determining their infection success, especially if repeated rain events cause further dispersal after their initial release from pycnidia. However, there has been little reported research on the survival of Botryosphaeriaceae species conidia exposed to solar radiation or dry conditions.

The purpose of this study was to determine the effects of (i) different levels and periods of solar radiation on survival of conidia, as measured by their ability to germinate, and (ii) different relative humidities on conidial germination.

\section{MATERIALS AND METHODS}

Effect of solar radiation and temperature on conidium viability

The conidial tendrils of N. luteum, N. australe and D. mutila that oozed from inoculated, green grapevine shoots (Amponsah et al. 2008) were each removed with the tip of a sterilised scalpel, 
mixed into a $20 \mu \mathrm{l}$ drop of sterile water on a glass slide, spread to cover about a $1 \mathrm{~cm}^{2}$ area and airdried immediately within a laminar flow cabinet. The air-dried conidium-laden glass slides were laid into square Petri dishes $\left(100 \mathrm{~mm}^{2}\right)$ lined with five layers of moist facial tissue and supported by plastic drinking straws.

The conidia were then exposed to three levels of solar radiation by covering the Petri dishes with different materials, supported on wooden blocks to create a $50 \mathrm{~mm}$ high ventilation gap. The radiation levels were: (1) filtered sunlight (-UV) with 1.5 mm thick Makrolon ${ }^{\circledR}$ UV Polycarbonate that allows penetration of only visible white light, (2) non-filtered sunlight (+UV) with a $1.5 \mathrm{~mm}$ Acrylic sheet, A-cast ${ }^{\mathrm{TM}}$, which allows penetration of both UV and visible white light, and (3) shade with 1.5 $\mathrm{mm}$ thick brown cardboard. The temperature within each type of Petri dish was recorded every 30 min with TinyTag Talk 2 temperature loggers (Gemini Data Logger UK Ltd). There were three slides per species for each level of sunlight exposure. The light exposure times were achieved over continuous periods of 1 to 5 days and repeated twice on separate days during 10 to 28 February 2010 when daylight hours for the period lasted 13.5-14.5 h each day (from sunrise to sunset). For every solar radiation treatment of each species, an extra slide of conidia was made and immediately observed (within 30 min of harvest) under a light microscope for presence of germination. They were then incubated under $100 \% \mathrm{RH}$ at $25^{\circ} \mathrm{C}$ and in continuous darkness for 12-24 h and observed again for viability. These samples served as non exposed (pretest) controls for comparison of percent germination with treatments.

\section{Effect of relative humidity $(\mathrm{RH})$ on conidial germination}

To determine the effects of different relative humidities $(\mathrm{RH})$ on conidial germination, saturated salts were prepared and poured into square Petri dishes that had been lined with five layers of facial tissue paper to soak up the saturated salt solution and to prevent spillage. Potassium chloride $(\mathrm{KCl})$, potassium nitrate $\left(\mathrm{KNO}_{3}\right)$, potassium sulphate $\left(\mathrm{KSO}_{4}\right)$ and water were used to achieve an approximated $\mathrm{RH}$ of $84,93,97$ and $100 \%$ respectively, at $25^{\circ} \mathrm{C}$ (Greenspan 1977). The lids were replaced and sealed with Parafilm ${ }^{\mathrm{TM}}$. The containers were left to equilibrate for $1 \mathrm{~h}$ at $25^{\circ} \mathrm{C}$, after which the conidium-laden slides of $N$. luteum, $N$. australe and D. mutila, prepared as described before, were each put into the equilibrated Petri dishes and incubated at $25^{\circ} \mathrm{C}$ for $3,6,24$ or $48 \mathrm{~h}$. The three replicates per treatment were set out in a completely randomised design.

\section{Assessment of conidium viability and statistical analysis}

At the end of every incubation period, the conidium-laden slides from both experiments were observed under the compound microscope at $\times 40$ magnification. Between 150 and 200 conidia were examined over the slide centre to allow counting of germinated and nongerminated conidia. A conidium was considered germinated when its germ tube was at least half the conidium length. On slides with zero germination the conidia were suspended in a drop of sterile water and this was spread onto PDA plates for incubation in the dark at $25^{\circ} \mathrm{C}$ for $48 \mathrm{~h}$, followed by examination under a stereo microscope at $\times 20$ magnification to confirm that the conidia had been killed, rather than germination being temporarily inhibited by the light exposure or RH. The data of percent germination, with species and treatments as separate factors, were analysed separately for each experiment by ANOVA using GenStat version 11. Treatment means were compared by Fisher's protected LSD tests at $\mathrm{P} \leq 0.05$.

\section{RESULTS \\ Effect of solar radiation and temperature on conidia viability}

The repeated experiments did not differ $(\mathrm{P}>0.05)$ in overall effects and the effects of solar radiation exposure on percent germination from the two repeated trials did not differ $(\mathrm{P}>0.05)$ between the species, $N$. australe, $N$. luteum and $D$. mutila, so these data were also combined for the second analysis. Germination of the conidia was 
significantly affected by light levels $(\mathrm{P}<0.001$; LSD $=1.94$ ), with shade, filtered solar radiation (-UV) and non-filtered solar radiation (+UV) having germination of $75.2,28.1 \%$ and $12.2 \%$ respectively, compared to the levels in the preset controls, which were $96.3 \%$. Increasing exposure times caused decreasing germination $(\mathrm{P}<0.001$; LSD $=2.75$ ), with an overall mean germination of $58.0 \%$ after $7 \mathrm{~h}$ exposure being significantly higher than that of $28.6 \%$ recorded after $70 \mathrm{~h}$ exposure (Figure 1a). There was a highly significant $(\mathrm{P}<0.001 ; \mathrm{LSD}=4.75)$ interaction between the exposure times and the radiation levels. The range of temperatures recorded under the three different radiation levels were $18-26^{\circ} \mathrm{C}$ for shade, $28-33^{\circ} \mathrm{C}$ for filtered solar radiation (-UV) and $21-28^{\circ} \mathrm{C}$ for non-filtered solar radiation (+UV). The highest temperature recorded under the radiation treatments was $41.3^{\circ} \mathrm{C}$, although under shade it reached $35^{\circ} \mathrm{C}$ for $30 \mathrm{~min}$ and $39^{\circ} \mathrm{C}$ for $1 \mathrm{~h}$, respectively, during the 7 and $14 \mathrm{~h}$ exposure times. Germination of conidia observed for 7-14 $h$ exposure under shade did not differ significantly from the $28 \mathrm{~h}$ exposure. Non-germinated conidia from the slides with zero germination $(+\mathrm{UV})$ failed to germinate after incubating on PDA for 3 days at $25^{\circ} \mathrm{C}$ in continuous darkness.

\section{Effect of relative humidity $(\mathrm{RH})$ on conidial germination}

The effects of $\mathrm{RH}$ on percent germination did not differ $(\mathrm{P}>0.05)$ between $N$. australe,
N. luteum and D. mutila and so these data were combined in the second analysis. The effects of the different $\mathrm{RH}$ levels and times on percent conidial germination were highly significant $(\mathrm{P}<0.001$; LSD $=0.96)$ (Figure 2$)$, as were the effects of exposure times $(\mathrm{P}<0.001$; LSD $=1.10)$ and the interaction between the $\mathrm{RH}$ level and times $(\mathrm{P}<0.001 ; \mathrm{LSD}=1.91)$. The RH of $100 \%$ resulted in the quickest and highest conidial germination of $91.8 \%$ within $3 \mathrm{~h}$, whereas in $97 \%$ $\mathrm{RH}$ it took $6 \mathrm{~h}$ for germination to reach $67.2 \%$, which was close to the maximum of $69.9 \%$ after $48 \mathrm{~h}$. In 93\% RH no conidia had germinated after 3 and 6 h but germination reached $43.9 \%$ after $24 \mathrm{~h}$, and $48.9 \%$ after $48 \mathrm{~h}$ (Figure 2). Conidia placed in 100 and $97 \%$ RH formed mycelial networks by $6 \mathrm{~h}$, but in $93 \% \mathrm{RH}$, the germinating conidia had not developed mycelium networks, even by $48 \mathrm{~h}$.

\section{DISCUSSION}

The exposure of Botryosphaeriaceae conidia to light reduced their viability in relation to the level of light and exposure time. Non-filtered solar radiation $(+\mathrm{UV})$ had the greatest effect compared with filtered solar radiation (-UV) and shade. The detrimental effect of UV was further shown by $0 \%$ germination after $56 \mathrm{~h}$ exposure with +UV compared to the $69 \%$ germination after the same time in the shade. Since the nongerminated conidia were still unable to germinate after plating onto PDA, this confirmed that they
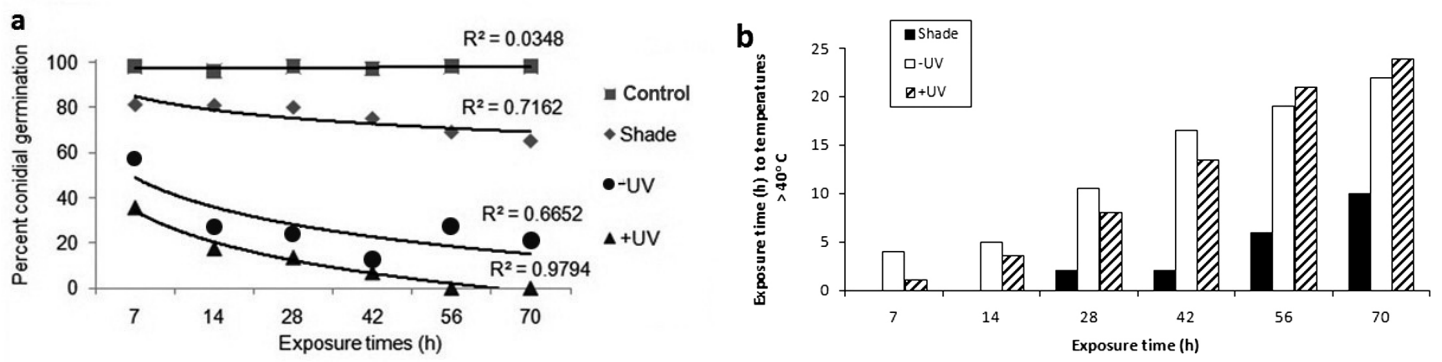

Figure 1 (a) Mean percent germination of Botryosphaeriaceae species conidia given different exposure times and levels of solar radiation (shade, filtered sunlight (-UV) or non-filtered sunlight (+UV)) and (b) hours at which conidia were exposed to temperatures greater than $40^{\circ} \mathrm{C}$ under the three levels of solar radiation. The lines were log transformed to provide the best fit. 


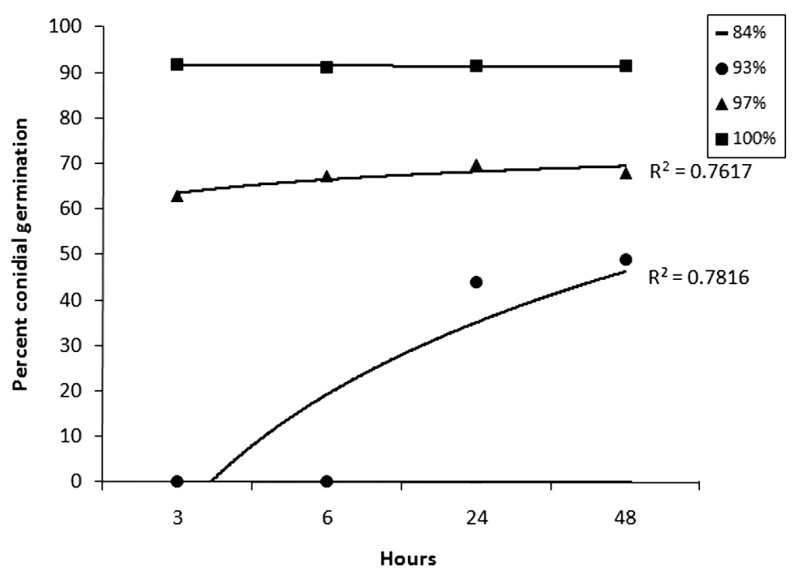

Figure 2 Mean percent germination of Botryosphaeriaceae species conidia during exposure to four levels of relative humidity ( $\mathrm{RH} ; 84,93,97$ or $100 \%)$ at $25^{\circ} \mathrm{C}$ for $3,6,24$ or $48 \mathrm{~h}$. The lines were $\log$ transformed to provide the best fit.

had been killed by the light exposure. The greater sunlight levels were also associated with longer periods of temperatures above $41^{\circ} \mathrm{C}$ (Figure $1 \mathrm{~b}$ ), which may have reduced conidium viability, although the data seem to indicate that the effect was unlikely to be due to temperature alone. Further studies should use an experimental setup that provides greater ventilation in an attempt to eliminate this potential effect. The damaging effects of UV light found in this study were also reported by Arabi et al. (2009) who observed that when conidia of Pyrenophora graminea were exposed to sunlight, decreased germinability and pathogenicity resulted. Similar observations were made on the lethal effects of UV in sunlight on germination of Puccinia striiformis uredospores (Maddison \& Manners 1972), and conidia of Alternaria solani (Rotem et al. 1985), Venturia inaequalis (Aylor \& Sanogo 1997), Peronospora tabaci, Uromyces phaseoli and Mycosphaerella fijiensis (Parnell et al. 1998).

The relatively high germinability of conidia kept in the shade treatment in this study was also observed by Maddison \& Manners (1972). Their investigation, conducted in England on relatively clear days in midsummer, found that germination of $P$. graminis uredospores was reduced to $10 \%$ by $20 \mathrm{~h}$ exposure to sunlight, whilst $6-10 \mathrm{~h}$ caused a similar reduction in germination of $P$. striiformis uredospores. However, in the present study germination of all three species of the Botryosphaeriaceae was not significantly different at the light levels tested.

The ability of conidia to germinate was also dependent on the supply of moisture through RH, since it was optimum at $100 \% \mathrm{RH}$, much reduced at $93 \% \mathrm{RH}$, with no germination at $84 \% \mathrm{RH}$ even after $72 \mathrm{~h}$ at the optimum growth temperature of $25^{\circ} \mathrm{C}$. This finding was in agreement with Arauz \& Sutton (1989) who also observed that maximum germination of $D$. seriata conidia occurred in free water and declined as $\mathrm{RH}$ was reduced from 100 to $92 \%$, with no germination at $88.5 \%$ RH. The conidia of another woody trunk pathogen, Potebniamyces pyri, were reported to have even more stringent requirements since no germination occurred at $95 \% \mathrm{RH}$, but $99 \%$ germinated at $98 \%$ RH (Liu \& Xiao 2005).

The RH levels also affected the extent of mycelial growth after germination. At 93\% RH the conidia that germinated after $24 \mathrm{~h}$ had not developed a mycelial network after another $24 \mathrm{~h}$, indicating that more moisture was necessary for mycelium growth and development. Arauz \& Sutton (1989) reported that conidia of D. seriata were very sensitive to drying and in no instance did the rewetted germ tubes resume growth following dryness periods of any duration unfortunately they did not specify the minimum dryness period. 
These studies indicated that disease cycles of Botryosphaeriaceae species involving conidia are most effective in rainy weather since they require moisture for germination. The conidia are released during high $\mathrm{RH}$, but if they are not supplied with continued high $\mathrm{RH}$ or free water they will not germinate. However, they will not even survive if exposed to UV light for 3 days or longer. Conidia released in early summer mornings may be exposed to sunlight for long periods, whilst those released during rainy, cloudy conditions can germinate quite quickly. A previous conidial trapping experiment (Amponsah et al. 2009) showed that conidia of Botryosphaeriaceae species were abundant in rain-splash during winter pruning of grapevines when the free moisture allows germination and many wounds are available for infection. However, the overall effects of the resulting cane dieback on vine death have not been reported. Further studies should be done to investigate the effects of the cooler winter temperatures on these processes. During summer, some parts of the grapevine canopy may provide sufficient shade and high $\mathrm{RH}$ to ensure rapid germination of conidia that can infect through the wounds created by summer trimming, which is usually conducted several times during the season.

In conclusion, this study has clearly shown that $\mathrm{RH}$ and UV light play a major role on the Botryosphaeriaceae species conidium viability. While low $\mathrm{RH}$ alone caused delays in conidium germination, the effect of UV light, possibly in combination with the associated high temperatures, killed the conidia outright. Botryosphaeriaceae species are therefore more likely to infect grapevine wounds in rainy, cloudy weather than dry, sunny weather.

\section{ACKNOWLEDGEMENT}

The authors thank New Zealand Winegrowers for funding this project.

\section{REFERENCES}

Amponsah NT, Jones EE, Ridgway HJ, Jaspers MV 2008. Production of Botryosphaeria species conidia using grapevine green shoots. New Zealand Plant Protection 61: 301-305.
Amponsah NT, Jones EE, Ridgway HJ, Jaspers MV 2009. Rainwater dispersal of Botryosphaeria conidia from infected grapevines. New Zealand Plant Protection 62: 228-233.

Arabi MIE, Al-Shehadah E, Jawhar M 2009. Viability of Pyrenophora graminea cultures after sunlight exposure under field conditions. Journal of Plant Pathology 91 (2): 299-302.

Arauz LF, Sutton TB 1989. Influence of temperature and moisture on germination of ascospores and conidia of Botryosphaeria obtusa. Phytopathology 79: 667-674.

Aylor DE, Sanogo, S 1997. Germinability of Venturia inaequalis conidia exposed to sunlight. Phytopathology 87: 628-633.

Greenspan, L 1977. Humidity fixed points of binary saturated aqueous solutions. Journal of Research of the National Bureau of Standards A. Physics and Chemistry 18A (1): 98(Abstract).

Lazzizera C, Frisullo S, Alves A, Phillips AJL 2008. Morphology, phylogeny and pathogenicity of Botryosphaeria and Neofusicoccum species associated with drupe rot of olives in southern Italy. Plant Pathology 57: 948-956.

Liu Q, Xiao CL 2005. Influence of nutrient and environmentalfactorson conidialgermination of Potebniamyces pyri. Phytopathology 95: 572-580.

Maddison AC, Manners JG 1972. Sunlight and viability of cereal rust uredospores. Transactions British Mycological Society 59(3): 429-443.

Parnell M, Burt PA, Wilson K 1998. The influence of exposure to ultraviolet radiation in simulated sunlight on ascospores causing Black Sigatoka disease of banana and plantain. International Journal of Biometeorology 42: 22-27.

Rotem J, Wooding B, Aylor DE 1985. The role of solar radiation, especially ultraviolet, in the mortality of fungal spores. Phytopathology 75: 510-514.

Slippers B, Wingfield M J 2007. Botryosphaeriaceae as endophytes and latent pathogens of woody plants: diversity, ecology and impact. Fungal Biology Reviews 21(2-3): 90-106. 